\title{
Carbon stable isotope ratio as a revealer of incomplete decarbonation for particulate organic carbon measurement in river plumes
}

\author{
Thierry Blasco $^{1} \cdot$ Christophe Migon $^{1} \cdot$ Guillaume Morin $^{1,2} \cdot$ Aurélie Dufour $^{1,3} \cdot$ Nathalie Vigier $^{1} \cdot$ Sabine Marty ${ }^{1,4}$. \\ David Doxaran ${ }^{1}$ (D)
}

Received: 4 June 2020 / Accepted: 19 October 2020 / Published online: 7 January 2021

(C) The Author(s) 2021

\begin{abstract}
The characterization of particles in suspension in river plumes contributes to the assessment of net particulate organic carbon (POC) fluxes and to a better understanding of the anthropogenic and climatic impact on blue carbon. Prior to POC analysis in natural waters, inorganic carbon (in the form of carbonates) must be removed. This step is generally carried out by acid leaching. However, the presence of mineral matrices (in turbid waters) may hinder total decarbonation, which may result in biased measurements. This work checks the quality of decarbonation through the analysis of carbon stable isotope ratio $\left(\delta^{13} \mathrm{C}\right)$, considering suspended particles discharged by three rivers into coastal waters under flooding conditions. Carbonates were removed by adding variable volumes of $2 \mathrm{~N}$ hydrochloric acid $(\mathrm{HCl})$ to filters. Carbon concentrations and stable isotopic ratios were analyzed. Values of $\delta^{13} \mathrm{C}_{\text {org }}$ (stable isotope ratio of organic carbon) allow the identification of incompletely decarbonated samples. If a small amount of detrital carbonates resists the usual decarbonation treatment, $\delta^{13} \mathrm{C}_{\text {org }}$ can be significantly shifted towards less negative values, suggesting the need of more efficient decarbonation methods in order to improve the accuracy of organic carbon measurements. Even in the case of a high $\mathrm{C}_{\mathrm{org}} / \mathrm{C}_{\text {total }}$ ratio, the impact of remaining carbonates on the $\delta^{13} \mathrm{C}_{\text {org }}$ value is strong because $\delta^{13} C_{\text {inorg }}$ is significantly different. The sensitivity of $\delta^{13} C_{\text {org }}$ measurement might therefore be used to validate POC measurements in estuarine and coastal waters.
\end{abstract}

Keywords $\delta^{13} \mathrm{C} \cdot$ Organic carbon $\cdot$ Estuaries $\cdot$ Decarbonation $\cdot$ River plumes $\cdot$ Suspended sediments

\section{Introduction}

Combining ocean color remote sensing observations (e.g., Lorthiois et al. 2012; Ody et al. 2016) with in situ sampling and laboratory analyses helps to characterize, chemically and

David Doxaran

david.doxaran@obs-vlfr.fr

1 Laboratoire d'Océanographie de Villefranche (LOV), Sorbonne Université/CNRS, 06230 Villefranche sur Mer, France

2 Present address: Geosciences Environnement Toulouse, UMR 5563, Toulouse, France

3 Present address: Mediterranean Institute of Oceanography (MIO), Marseille, France

4 Present address: Norwegian Institute for Water Research (NIVA), Oslo, Norway mineralogically, suspended particles in river plumes, in particular the nature and origin of particulate organic carbon (POC). Many former studies showed correlation between organic carbon (OC) in estuaries and environmental factors, i.e., anthropic pressure or rainfall (e.g., Abril et al. 2002), and the anthropogenic impacts on blue carbon, i.e., carbon captured by marine living organisms (Kuwae et al. 2016). For this purpose, protocols have been recently reviewed by the ocean color community for sample collection, filtration, storage, analysis, and quality assurance in the scope of POC measurements appropriate for satellite algorithm development and validation (Chaves et al. 2019).

There is growing evidence of a link between climate change and the increase in extreme meteorological events such as floods and droughts (IPCC 2012). The northwestern Mediterranean Sea is known to be significantly impacted by climate change (Metzger et al. 2005; Kim et al. 2019) and is 
often subject to extreme precipitation events and subsequent floods (Colmet-Daage et al. 2018). It has been shown that a shift to more extreme precipitation events (more heavy rainfall and longer dry intervals) alters estuarine salinity and temperature, carries nutrients, organic matter, and contaminants, and alters the structure of phytoplanktonic and coastal microbial communities (e.g., Pollack et al. 2011; Wetz and Yoskowitz 2013; Zoppini et al. 2019). Besides, the discharge of riverine suspended particles to coastal waters often results in the alteration of their chemical composition. Characterization of carbon riverine inputs in estuaries is well documented (e.g., Cathalot et al. 2013), but not under peak flooding conditions, a less documented research field.

Organic carbon analyses are not simple, notably because organic phases are often intimately associated with inorganic phases (King et al. 1998). Carbon is commonly considered in two major forms, organic (OC) and inorganic (IC), having distinct isotopic signatures, e.g., $\delta^{13} \mathrm{C}_{\mathrm{org}}=-25$ to $-30 \%$ for POC of Rhône River (Harmelin-Vivien et al. 2010), $\delta^{13} \mathrm{C}_{\text {inorg }}=0$ to $2 \%$ for dissolved IC in tropical waters (Cotovicz et al. 2019), and -5 to $0 \%$ in Mediterranean waters close to the Rhône River mouth (Pozzato et al. 2018). The removal of IC forms is generally carried out by acid treatment ("decarbonation"), usually with hydrochloric acid ( $\mathrm{HCl})$, prior to POC analysis, assuming that most of this carbon is contained into calcium carbonate phases. Acidification is carried out either in direct aqueous solution or in vaporous mode (fumigation) (Komada et al. 2008). However, leaching of soluble OC may occur (Froelich 1980), as well as the release of non-carbonate inorganic matter, which may lead to an overestimation of the OC content if not properly dried (Hedges and Stern 1984). Several methods have been developed to overcome these potential biases (Nieuwenhuize et al. 1994). Inefficient carbonate removal has been reported for diluted acid solutions $(0.1 \mathrm{~N})$, and potential alteration of $\mathrm{OC}$ has been reported for concentrated solutions $(6 \mathrm{~N})$. Many protocols use diluted $\mathrm{HCl} 1 \mathrm{~N}$ or $2 \mathrm{~N}$ (e.g., Darnaude et al. 2004) in aqueous phase. Fumigation is often recommended (Liénart et al. 2017), but the use of more concentrated acid may induce partial loss of OC if the sample is overexposed (Komada et al. 2008). There is no consensus on the most appropriate method to use, depending of the samples studied (Brodie et al. 2011).

This work proposes to use stable carbon isotope analysis to verify the completeness of the decarbonation process for suspended particles in river plumes. Three rivers are considered owing to the different mineralogy and chemical matrix of their particulate discharge. The results obtained on natural samples collected in river plumes show a significant heterogeneity of the isotopic signatures of OC $\left(\delta^{13} \mathrm{C}_{\text {org }}\right)$ among samples, without being able to say whether this results from a real chemical heterogeneity (most likely due to different terrigenous loads) or from an incomplete sample decarbonation. This question is the purpose of the present note.

\section{Material and methods}

\section{Study sites and sampling}

Mediterranean rivers experience annual peak floods during the winter and spring seasons. The three study areas selected here are the Rhône, Var, and Paillon Rivers (south-east Mediterranean coast of France) (Fig. 1). The Rhône is a major river of the northwestern Mediterranean Sea while the Var and Paillon are typical peak flood rivers, with average freshwater discharges of 1690,50 , and 1 to $40 \mathrm{~m}^{3} \mathrm{~s}^{-1}$, respectively, and watershed surface areas of 95,590, 2800, and $236 \mathrm{~km}^{2}$.

Water samples were collected during flooding conditions in the Rhône (February 2016, 51 stations), Var (24 stations, November 2016), and Paillon (18 stations, November 2016) plumes. Surface waters (0-1 m depth, i.e., within the surface layer viewed by satellite ocean color sensors) were collected using horizontal 8L-Niskin bottles, from the river mouth to the offshore edge of the turbid plume. Each bottle was split in three sub-samples to triplicate measurements. In addition, 20L-samples were collected a few meters upstream the mouths of the Var and Paillon Rivers to sample large amounts of suspended particles for mineralogical determination, to be compared to results from the Rhône River (Pont et al. 2017).

\section{Sample preparation}

Known volumes of water samples ( $V=0.2$ to $0.6 \mathrm{~L}$, depending on water turbidity) were filtered through pre-combusted $\left(1 \mathrm{~h}\right.$ at $\left.450{ }^{\circ} \mathrm{C}\right)$ and pre-weighed (mass $\mathrm{M}_{0}$, in $\mathrm{mg}$ ) $25 \mathrm{~mm}$ glass-fiber filters (Whatman, GF/F). The three sub-samples were filtered, resulting in three filters (triplicates) for each sampling point. Filters were then dried for $24 \mathrm{~h}$ at $60^{\circ} \mathrm{C}$, prior to weighing under dry atmosphere (mass $\mathrm{M}_{1}$, in $\mathrm{mg}$ ) to obtain the suspended particulate matter concentration (SPM, in $\mathrm{mg}$ / $\mathrm{L})$ as $\mathrm{SPM}=\left(M_{1}-M_{0}\right) / V$. The uncertainty associated to SPM measurements was assumed to be the standard deviation on triplicates $(<5 \%)$. The first data set for isotopic analysis was carried out after removal of carbonates by adding $20 \mu \mathrm{L} \mathrm{HCl}$ $2 \mathrm{~N}$ several times, until the effervescence caused by acidification was no longer observable, according to a widely used standard protocol (King et al. 1998), here called "protocol \#1." On many filters, this effervescence was unusually low and disappeared after the second addition of acid. A decarbonation problem was suspected, and, in order to address this problem, analyses on sub-samples from the same sampling campaign were carried out using an alternative protocol characterized by more intensive acid leaching ( 200 to $350 \mu \mathrm{L}$ of $\mathrm{HCl} 2 \mathrm{~N}$ on each filter, according to the sample mass) and hereinafter referred to as "protocol \#2." This amount of acid, able to achieve decarbonation of samples weighing more than $20 \mathrm{mg}$, is in large excess relative to the limit value measured for certified marine sediments $(6 \mu \mathrm{L} / \mathrm{mg}$, see below). 
Fig. 1 a Location of the three river mouths and plumes (northwestern Mediterranean Sea) selected as study areas. Locations of sampling stations in the $\mathbf{b}$ Rhône, c Var, and Paillon River plumes and $\mathbf{d}$ typical water samples collected at the mouths of the Var "V" and Paillon "P" Rivers

\section{Analyses}

Particulate fractions collected on GF/F filters were analyzed by isotope ratio mass spectrometry (IRMS). Samples collected upstream the river mouths underwent mineralogical analyses.

\section{Carbon stable isotope analysis $\left(\delta^{13} \mathrm{C}\right)$}

Filters were analyzed for both carbon isotopes and concentrations using an Elemental Analyzer (Elementar
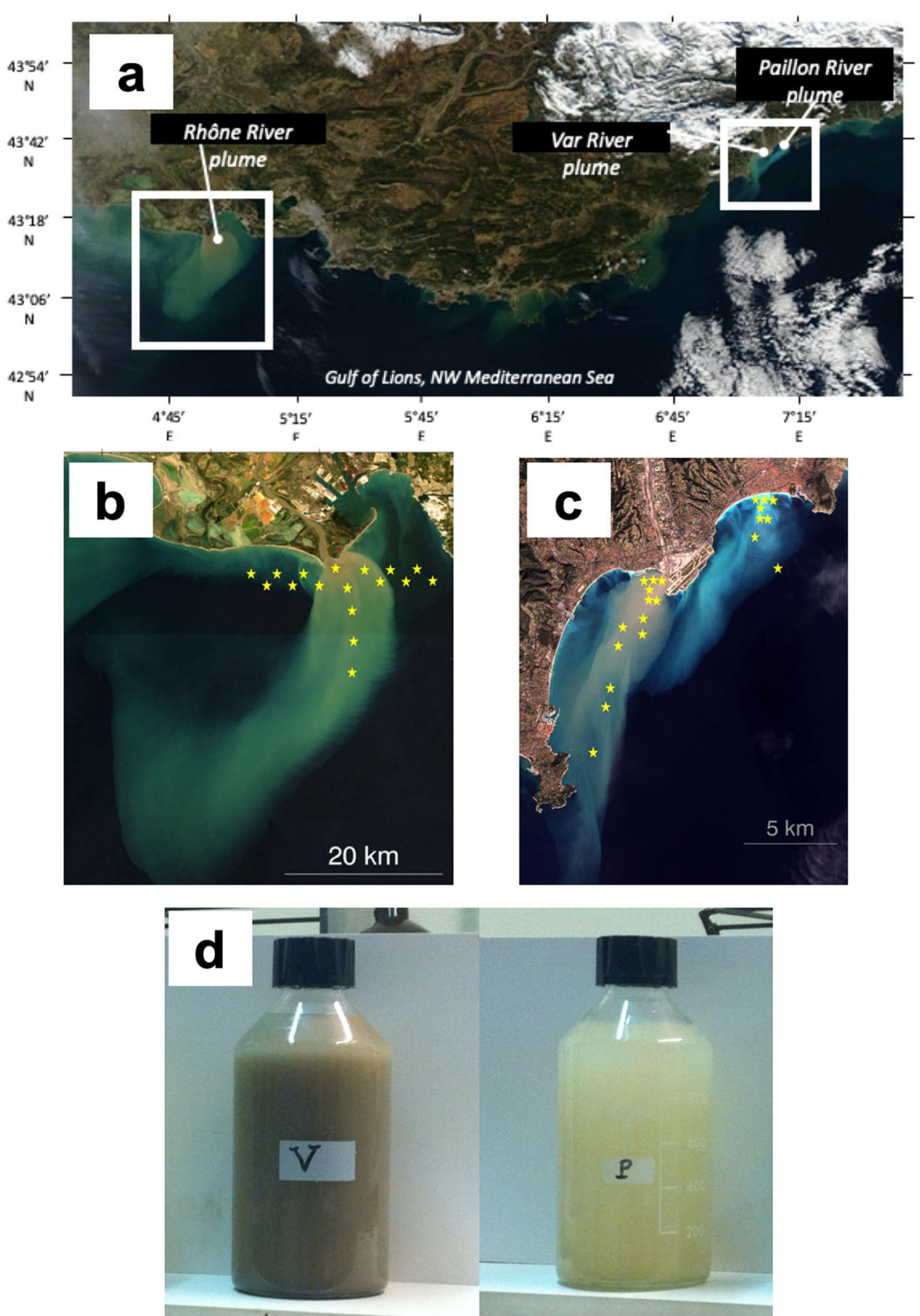

VarioPyroCube) coupled to an isotope ratio mass spectrometer (Isoprime 100). All isotopic data are expressed in conventional notation (Eq. 1), as the isotopic ratio normalized to the reference gas:

$\delta_{\text {sample }}=\left[\left(R_{\text {sample }} / R_{\text {ref }}\right)-1\right]$

where $\delta_{\text {sample }}$ is expressed in \%o, and $R_{\text {sample }}$ and $R_{\text {ref }}$ are the isotopic ratios $R={ }^{13} \mathrm{C} /{ }^{12} \mathrm{C}$ of the sample and the reference gas, respectively. 
Certified standard IAEA-600 caffeine was used in each batch for isotopic data monopoint correction (Paul et al. 2007), according to Eq. 2:

$\delta^{13} \mathrm{C}^{\mathrm{c}}$ sample $=\left(\delta^{13} \mathrm{C}^{\mathrm{m}}\right.$ sample +1000$) \times\left(\delta^{13} \mathrm{C}_{\text {standard }}^{\mathrm{t}}+1000\right) /\left(\delta^{13} \mathrm{C}_{\text {standard }}^{\mathrm{m}}+1000\right)-1000$

$\delta^{13} \mathrm{C}^{\mathrm{c}}$ sample : corrected $\delta^{13} \mathrm{C}$ value for sample, in $\%$ o

$\delta^{13} \mathrm{C}_{\text {sample }}^{\mathrm{m}}$ : measured $\delta^{13} \mathrm{C}$ value for sample, in\%o

$\delta^{13} \mathrm{C}_{\text {standard }}^{\mathrm{t}}$ : certified $\delta^{13} \mathrm{C}$ value for standard, in\%o

$\delta^{13} \mathrm{C}^{\mathrm{m}}$ standard : measured $\delta^{13} \mathrm{C}$ value for standard, in\%o

Each run of 30 samples started with two measurements of isotopically certified caffeine (IAEA- $600, \delta{ }^{13} \mathrm{C}_{\text {standard }}^{\mathrm{t}}=$ $-27.771 \%$ o, $\mathrm{SD}=0.043$ ) and ended with two other measurements of the same certified standard. Bracketing every six samples in each batch was carried out using acetanilide (Merck KGaA), widely used to calibrate the response of the elemental analyzer and used in the laboratory as a secondary IRMS standard, corrected by caffeine $\delta^{13} \mathrm{C}$ measurements. Measurements of $\delta^{13} \mathrm{C}$ in acetanilide showed standard deviation for all batches lower than $0.1 \%$, and the average measured carbon mass content was $71.16 \%, \mathrm{SD}=1.16 \%$ (the theoretical value for pure compound is $71.09 \%$ ). The standard deviation was higher for $\% \mathrm{C}$ than for $\mathrm{C} / \mathrm{N}$, because of the uncertainty on the small sample weight that impacted \%C calculation.

\section{Mineralogy}

After centrifuging, particle samples from bottles collected upstream the river mouths were dry-weighed, and then smoothly reduced to powder in an agate mortar. Analyses were carried out with a Siemens D5000 X-ray diffractometer (Bruker) mounted in Bragg-Brentano $\vartheta / \vartheta$ geometry with a 3 to $65^{\circ}$ scanning by steps of $0.04^{\circ}$ during $10 \mathrm{~s}$. The diffractometer was equipped with an $\mathrm{X}$-ray tube fitted with a copper anticathode with a $40 \mathrm{kV}$ accelerating voltage and $30 \mathrm{~mA}$ current. Analyses were conducted on bulk samples (including all minerals) and on separated clay samples. Results provided semi-quantitative proportions of minerals.

\section{Results}

\section{Reference materials}

The acidification protocol was first tested on reference samples. Certified marine sediment samples (MESS-2, from NRCC, Canada, $\% \mathrm{C}_{\text {total }}=2.14 \% \pm 0.03$ ) were analyzed without acidification, giving an averaged measured $\% \mathrm{C}_{\text {total }}$ value of $2.17 \%$, with a standard deviation (SD) of $0.07 \%$, in accordance with the certified value. The average isotopic measurement for total carbon, i.e., without acidification, was $\delta^{13} \mathrm{C}_{\text {total_MESS2 } 2}=-18.25 \%$, $\mathrm{SD}=0.06 \%$.

A new set of MESS-2 samples acidified with various $\mathrm{HCl}$ $2 \mathrm{~N}$ volumes, covering the ranges of both protocols in microliters per milligram of sample, and sample masses were analyzed. Variability on $\delta^{13} \mathrm{C}$ measurements was significant for added $2 \mathrm{~N}$ HCL volumes lower than $6 \mu \mathrm{L}$ per mg of sample mass (Fig. 2), an amount similar to the volume proposed by Lukasewycz and Burkhard (2005).

This variation of $\delta^{13} \mathrm{C}$ depending on the amount of acid is typical of a two end-member mixing model (Loftis and Meile 2014):

$\delta^{13} \mathrm{C}_{\text {mix }}=\mathrm{x}_{\text {Corg }} \times \delta^{13} \mathrm{C}_{\text {org }}+\mathrm{x}_{\text {Cinorg }} \times \delta^{13} \mathrm{C}_{\text {inorg }}$

with $1=\Sigma \mathrm{x}_{\mathrm{i}}, \mathrm{x}_{\text {Corg }}$, and $\mathrm{x}_{\text {Cinorg }}$ are the organic and inorganic fractions of carbon, respectively.

For MESS-2 samples, according to Eq. 3:

$$
\begin{aligned}
\delta^{13} \mathrm{C}_{\text {mix }} & =\delta^{13} \mathrm{C}_{\text {total }}=-18.25 \%, \mathrm{SD}=0.06 \% \text {, and } \delta^{13} \mathrm{C}_{\mathrm{org}} \\
& =-25.91 \%, \mathrm{SD}=0.13 \% \text {, with } \mathrm{x}_{\text {Corg }}=0.57
\end{aligned}
$$

\section{Field samples}

Particles from samples collected upstream the river mouths were mineralogically analyzed (Table 1). Particles in the Var River can contain more than twice the amount of clays compared to particles from the Paillon River.

IRMS analyses were performed on samples collected in the river plumes. Samples acidified with the two protocols were grouped and randomly ordered for daily analysis subsets. Figure $3 \mathrm{a}$ displays the $\mathrm{OC}$ isotope ratios $\left(\delta^{13} \mathrm{C}_{\mathrm{org}}\right)$ measured as a function of the SPM concentration for samples acidified with protocol \#1.

A strong heterogeneity can be observed (Fig. 3a), with $\delta^{13} \mathrm{C}_{\text {org }}$ values decreasing seaward (towards low SPM), in

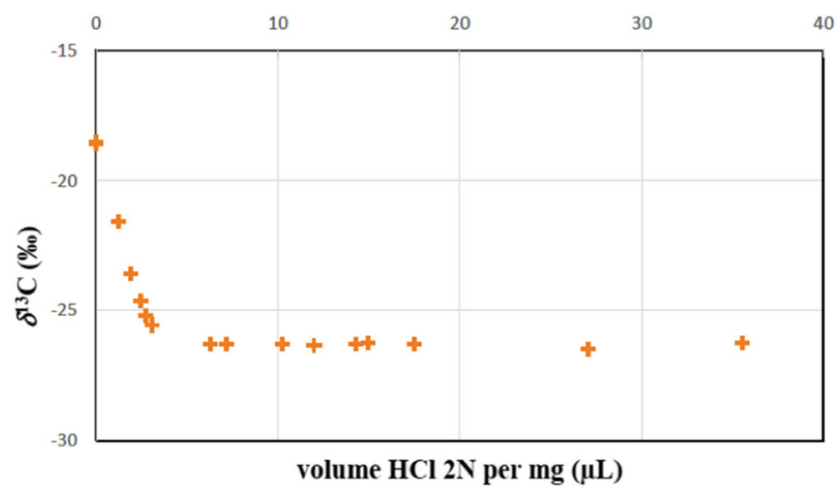

Fig. 2 Isotopic ratios of MESS-2 organic carbon as a function of the added volume of $2 \mathrm{~N}$ HCL per mg of sample: $\delta^{13} \mathrm{C}(\% \circ)=f($ volume $2 \mathrm{~N}$ $\mathrm{HCl}$ per $\mathrm{mg}(\mu \mathrm{L} / \mathrm{mg}))$. The size of points represents the measurement reliability $(0.1 \%$ o $)$ 
Table 1 Relative abundances (\%) of clays, quartz, feldspars, and carbonates (calcite and dolomite) in particles in suspension in the Paillon and Var Rivers based on X-ray diffraction analysis. Suspended particles in the Rhône River contain significant amount of clays (Pont et al. 2017)

\begin{tabular}{llllll}
\hline & Clays & Quartz & Feldspars & Carbonates: calcite & Carbonates: dolomite \\
\hline Paillon River mouth & 10 & 14 & 6 & 70 & 1 \\
Paillon River & 10 & 14 & 1 & 73 & 54 \\
Var River mouth & 20 & 19 & 6 & 57 & 1 \\
Var River & 17 & 17 & 7 & 2 \\
\hline
\end{tabular}

particular in the Rhône (from -16.1 to $-27.7 \%$ o) and $\operatorname{Var}(-5$ to $-26 \%$ ) plumes. This suggests the presence of strong mineral matrices in river loads and the occurrence of terrigenous inputs, which are both likely to make more difficult the total removal of carbonates using the applied protocol. Significant loads of clays might reduce the efficiency of the standard decarbonation protocol and, therefore, yield shifted isotopic measurements, i.e., less negative values, if $\delta^{13} \mathrm{C}_{\mathrm{org}}$ is different from $\delta^{13} \mathrm{C}_{\text {inorg }}$ (see Eq. 3).

The two decarbonation protocols were then applied to suspended particles from the Rhône River (clay-rich matrix) and Paillon River (negligible matrix effect) (Fig. 3b) plumes.
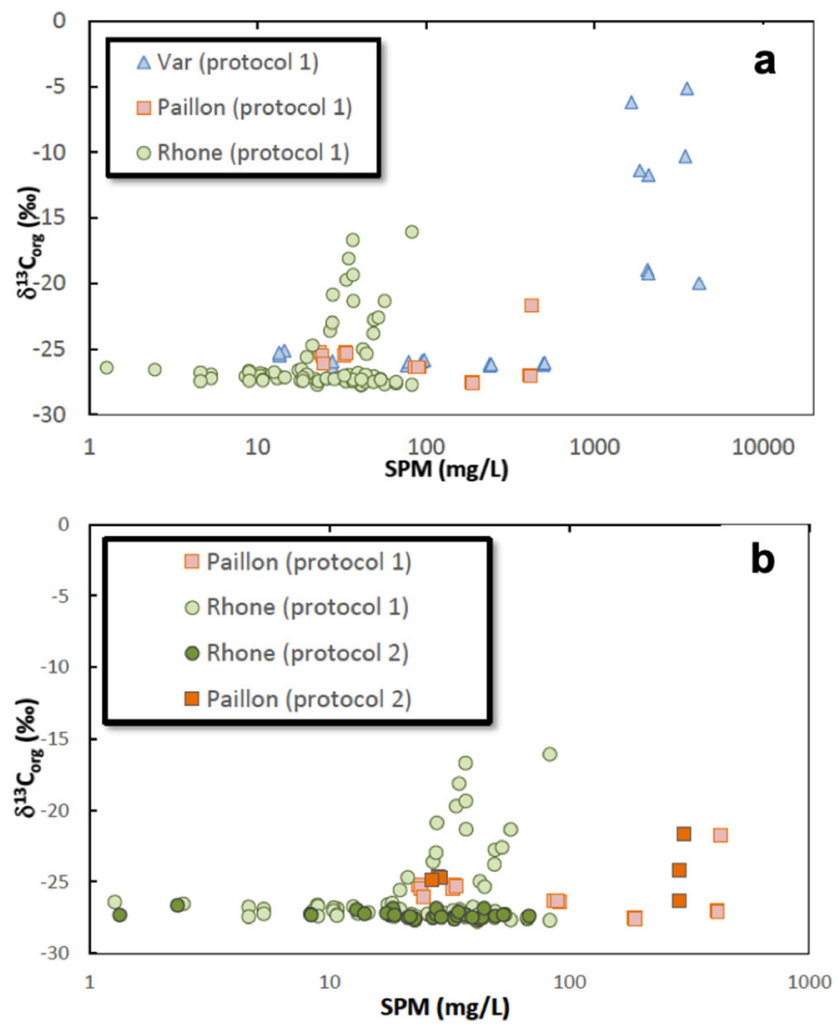

Fig. 3 a Carbon isotope ratios $\left(\delta^{13} \mathrm{C}_{\text {org }}\right)$ obtained using protocol \#1 (standard decarbonation) as a function of SPM concentration, for the three sampled river plumes. b $\delta^{13} \mathrm{C}_{\mathrm{org}}$ ratios obtained using protocol \#1 and protocol \#2, for the Rhône and Paillon Rivers, as a function of SPM concentration. The size of points represents the measurement reliability $(0.5 \% \circ)$
For the Rhône, samples acidified with protocol \#1 yielded heterogeneous results with less negative $\delta^{13} \mathrm{C}_{\text {org }}$ values (from -16.1 to $-27.7 \%$ ) exhibit more homogenous isotopic ratios when acidified with protocol \#2 (from -26.9 to $-27.7 \%$ ). Moreover, the samples acidified with protocol \#1, yielding the most negative $\delta^{13} \mathrm{C}_{\text {org }}$ values (generally those with a low SPM value), exhibit fairly similar isotopic ratios when acidified according to protocol \#2: protocol \#1 is clearly less efficient for samples close to the river mouths (i.e., with high SPM concentrations).

\section{Discussion}

During flood events, Mediterranean rivers discharge large amounts of mineral-rich SPM (mainly clays, silts, and fine sands, Table 1) in coastal waters. POC represents only a very low fraction of total SPM at the river mouths, and the POC/ SPM ratio typically increases with the distance from the coast with increasing proportion of organic-rich particles, i.e., phytoplankton cells and associated detrital organic matter. This feature is common to most world river plumes (Ludwig et al. 1996; Doxaran et al. 2012), and it was observed in the three sampled river plumes. Samples collected close to the river mouths presumably contain particles characterized by a heavier mineral matrix likely to perturb the sample pre-treatment required for carbon isotope or POC measurement.

The present results (Fig. 3b) suggest that the heterogeneity of $\delta^{13} \mathrm{C}_{\text {org }}$ values observed with the standard decarbonation protocol (protocol \#1) was attributable to matrix effect in high SPM or OC-poor waters. Thus, the standard decarbonation protocol might not be suitable for estuarine environments where suspended particles exhibit high amounts of clays. This hypothesis is strengthened by the relatively low shift of $\delta^{13} \mathrm{C}_{\text {org }}$ toward high values observed in the Paillon discharge: the mineral matrix effect is presumably stronger in the Rhône and Var discharges, chiefly due to the abundance of clays in their beds (see Table 1 for the Var and Pont et al. 2002 for the Rhône), which might alter $\delta^{13} \mathrm{C}_{\text {org }}$ analysis.

The mineralogical analysis of samples (Table 1) confirms the differences visually observed between water samples collected at the mouths of the Var and Paillon Rivers (Fig. 1d): 
there is significantly more clay in the Var than in the Paillon waters (20 vs $10 \%$, respectively). One may thus infer that clay-rich suspended particles are likely to hinder total decarbonation. Regarding the Rhône River, mineralogical analyses were missing in the present work, but some studies have pointed out the relatively high content in illite and chlorite clay minerals in this river (Pont et al. 2002). According to dissolution kinetics studies (Morera-Chavarría et al. 2016), detrital dolomite ( $\mathrm{Ca}$ and $\mathrm{Mg}$-rich carbonate) and siderite (Fe-rich carbonate) are more resistant to acid decarbonation than detrital calcite or, by extrapolation, calcareous phytoplankton cells. The Paillon particles contain a relatively high content of carbonates, while calcite and dolomite contents are roughly similar between the Paillon and Var Rivers (Table 1). This suggests that the abundance of carbonates does not significantly perturb the decarbonation process.

It is noteworthy that, if the POC content (\%POC) is only slightly affected by the classical decarbonation protocol (Lorrain et al. 2003), the impact on $\delta^{13} \mathrm{C}_{\mathrm{org}}$ is expected to be strong and may only refer to a small fraction of the total mass composed of remaining carbonates with significantly different $\delta^{13} \mathrm{C}_{\text {inorg }}$ value.

\section{Conclusions}

The physicochemical composition of suspended particles in the mouths and plumes of three rivers during floods has been analyzed. The elemental and isotopic analyses of POC show a strong heterogeneity, which results from the protocol used to remove carbonates. This study shows that carbon isotopic variability can be used to validate the results of the OC elemental analysis and to ensure the completeness of the decarbonation protocol.

Analyses of POC in natural water samples require a compromise between efficiency of decarbonation and preservation of $\mathrm{OC}$, both in nature and in concentration. The extent to which the POC content may be affected by the decarbonation method varies significantly according to (i) the mineral or chemical matrix characterizing the sample (salty water, estuarine water, sediment, clays, dolomite, etc.) and (ii) the decarbonation protocol, i.e., mainly, the type (e.g., hydrochloric, phosphoric or sulfuric) and amount of acid used. Basically, the stronger the matrix, the greater the amount of acid needed, and the greater the risk of losing OC. Most of the protocols seem nowadays suitable for measurements of OC concentration. However, this work shows that isotopic signatures may be much more sensitive to partial decarbonation. Measurements of $\% \mathrm{C}_{\text {org }}$ may be biased by partial decarbonation in high SPM waters, and the consideration of $\delta^{13} \mathrm{C}_{\mathrm{org}}$ values thus permits the determination of whether the remaining $\mathrm{C}$ is homogenous and actually exhibits a representative isotopic signature. Therefore, the $\delta^{13} \mathrm{C}_{\text {org }}$ heterogeneity may be used to control the quality of the POC data for estuarine environments, and the efficiency of the decarbonation protocol.

Acknowledgments This work was supported by the French Space Agency (CNES) through the TTC TOSCA project.

Open Access This article is licensed under a Creative Commons Attribution 4.0 International License, which permits use, sharing, adaptation, distribution and reproduction in any medium or format, as long as you give appropriate credit to the original author(s) and the source, provide a link to the Creative Commons licence, and indicate if changes were made. The images or other third party material in this article are included in the article's Creative Commons licence, unless indicated otherwise in a credit line to the material. If material is not included in the article's Creative Commons licence and your intended use is not permitted by statutory regulation or exceeds the permitted use, you will need to obtain permission directly from the copyright holder. To view a copy of this licence, visit http://creativecommons.org/licenses/by/4.0/.

\section{References}

Abril G, Nogueira M, Etcheber H, Cabeçadas G, Lemaire E, Brogueira MJ (2002) Behaviour of organic carbon in nine contrasting European estuaries. Est Coast Shelf Sci 54:241-262. https://doi. org/10.1006/ecss.2001.0844

Brodie CR, Leng MJ, Casford JSL, Kendrick CP, Lloyd JM, Yongqiang Z, Bird ML (2011) Evidence for bias in $\mathrm{C}$ and $\mathrm{N}$ concentrations and $\delta 13 \mathrm{C}$ composition of terrestrial and aquatic organic materials due to pre-analysis acid preparation methods. Chemical Geology 282:6783. https://doi.org/10.1016/j.chemgeo.2011.01.007

Cathalot C, Rabouille C, Tisnérat-Laborde N, Toussaint F, Kerhervé P, Buscail R, Loftis K, Sun MY, Tronczynski J, Azoury S, Lansard B, Treignier C, Pastor L, Tesi T (2013) The fate of river organic carbon in coastal areas: a study in the Rhône River delta using multiple isotopic $\left(\delta^{13} \mathrm{C}, \Delta^{14} \mathrm{C}\right)$ and organic tracers. Geochimica et Cosmochimica Acta 118:33-55. https://doi.org/10.1016/j.gca. 2013.05.001

Chaves JE, Cetinić I, Dall’Olmo G, Estapa M, Gardner W, Goñi M, Graff JR, Hernes P, Lam PJ, Liu Z, Lomas MW, Mannino A, Novak MG, Turnewitsch R, Werdell PJ, Westberry TK (2019) Particulate organic carbon sampling and measurement protocols: consensus towards future ocean color missions. International Ocean Colour Coordinating Group report, https://ioccg.org/what-we-do/ioccgpublications/, $48 \mathrm{pp}$.

Colmet-Daage A, Sanchez-Gomez E, Ricci S, Llovel C, Borrell Estupina V, Quintana-Seguí P, Llasat MC, Servat E (2018) Evaluation of uncertainties in mean and extreme precipitation under climate change for northwestern Mediterranean watersheds from highresolution Med and Euro-CORDEX ensembles. Hydrol Earth System Sci 22:673-687. https://doi.org/10.5194/hess-22-673-2018

Cotovicz L, Knoppers B, Deirmendjian L, Abril G (2019) Sources and sinks of dissolved inorganic carbon in an urban tropical coastal bay revealed by $\delta^{13} \mathrm{C}$-DIC signals. Est Coast Shelf Sci 220:185-195. https://doi.org/10.1016/j.ecss.2019.02.048

Darnaude AM, Salen-Picard C, Polunin NVC, Harmelin-Vivien ML (2004) Trophodynamic linkage between river runoff and coastal fishery yield elucidated by stable isotope data in the Gulf of Lions (NW Mediterranean). Oecologia 138:325-332. https://doi.org/10. 1007/s00442-003-1457-3

Doxaran D, Ehn J, Bélanger S, Matsuoka A, Hooker S, Babin M (2012) Optical characterization of suspended particles in the Mackenzie River plume (Canadian Arctic Ocean) and implications for ocean 
colour remote sensing. Biogeosciences 9:3213-3229. https://doi. org/10.5194/bg-9-3213-2012

Froelich PN (1980) Analysis of organic carbon in marine sediment. Limnology and Oceanography 25:564-572. https://doi.org/10. 4319/10.1980.25.3.0564

Harmelin-Vivien M, Dierking J, Bănaru D, Fontaine MF, Arlhac D (2010) Seasonal variation in stable $\mathrm{C}$ and $\mathrm{N}$ isotope ratios of the Rhone River inputs to the Mediterranean Sea (2004-2005). Biogeochem 100:139-150. https://doi.org/10.1007/s10533-0109411-z

Hedges JI, Stern JH (1984) Carbon and nitrogen determinations of carbonate containing soils. Limnology and Oceanography 29:756-763. https://doi.org/10.4319/1o.1984.29.3.0657

IPCC (2012) Managing the Risks of Extreme events and Disasters to Advance Climate Change Adaptation. A Special Report of Working Groups I and II of the Intergovernmental Panel on Climate Change [Field, C.B., V. Barros, T.F. Stocker, D. Qin, D.J. Dokken, K.L. Ebi, M.D. Mastrandrea, K.J. Mach, G.-K. Plattner, S.K. Allen, M. Tignor, and P.M. Midgley (eds.)]. Cambridge University Press, Cambridge, UK, and New York, NY, p 582

Kim G, Seo K, Chen D (2019) Climate change over the Mediterranean and current destruction of marine ecosystem. Scientific Reports 9: 18813. https://doi.org/10.1038/s41598-019-55303-7

King P, Kennedy H, Newton PP, Jickells TD, Brand T, Calvert S, Cauwet G, Etcheber H, Head B, Khripounoff A, Manighetti B, Miquel J (1998) Analysis of total and organic carbon and total nitrogen in settling oceanic particles and a marine sediment: an interlaboratory comparison. Marine Chemistry 60:203-2016. https://doi.org/10. 1016/S0304-4203(97)00106-0

Komada T, Anderson MR, Dorfmeier CL (2008) Carbonate removal from coastal sediments for the determination of organic carbon and its isotopic signatures, $\delta^{13} \mathrm{C}$ and $\Delta{ }^{14} \mathrm{C}$ : comparison of fumigation and direct acidification by hydrochloric acid. Limnology and Oceanography: Methods 6:254-262. https://doi.org/10.4319/lom. 2008.6.254

Kuwae T, Kanda J, Kubo A, Nakajima F, Ogawa H, Sohma A, Suzumura M (2016) Blue carbon in human-dominated estuarine and shallow coastal systems. Ambio 45:290-301. https://doi.org/10.1007/ s13280-015-0725-x

Liénart C, Savoye N, Bozec Y, Breton E., Conan P., David V., Feunteun E., Grangeré K., Kerhervé P., Lebreton B., Lefebvre S., L'Helguen S., Mousseau L., Raimbault P., Richard P., Riera P., Sauriau P.G., Schaal G., Aubert F., Aubin S., Bichon S., Boinet C., Bourasseau L., Bréret M., Caparros J., Cariou T., Charlier K., Claquin P., Cornille V., Corre A.M., Costes L., Crispi O., Crouvoisier M., Czamanski M., del Amo Y., Derriennic H., Dindinaud F., Durozier M., Hanquiez V., Nowaczyk A., Devesa J., Ferreira S., Fornier M., Garcia F., Garcia N., Geslin S., Grossteffan E., Gueux A., Guillaudeau J., Guillou G., Joly O., Lachaussée N., Lafont M., Lamoureux J., Lecuyer E., Lehodey J.P., Lemeille D., Leroux C., Macé E., Maria E., Pineau P., Petit F., Pujo-Pay M., Rimelin-Maury P., Sultan E. (2017) Dynamics of particulate organic matter composition in coastal systems: a spatio-temporal study at multi-systems scale. Progr Oceanogr 156:221-239. https://doi.org/10.1016/j. pocean.2017.03.001

Loftis KM, Meile C (2014) Isotopes and elemental ratios in multiparameter mixing models. Limnology and Oceanography: Methods 12:694-702. https://doi.org/10.4319/lom.2014.12.694

Lorrain A, Savoye N, Chauvaud L, Paulet YM, Naulet N (2003) Decarbonation and preservation method for the analysis of organic $\mathrm{C}$ and $\mathrm{N}$ contents and stable isotope ratios of low-carbonated suspended particulate material. Analytica Chimica Acta 491:125133. https://doi.org/10.1016/S0003-2670(03)00815-8

Lorthiois T, Doxaran D, Chami M (2012) Daily and seasonal dynamics of suspended particles in the Rhône River plume based on remote sensing and field optical measurements. Geo-Marine Letters 32: 89, 101. https://doi.org/10.1007/s00367-012-0274-2

Ludwig W, Probst JL, Kempe S (1996) Predicting the oceanic input of organic carbon by continental erosion. Global Biogeochem Cycles 10:23-41. https://doi.org/10.1029/95GB02925

Lukasewycz MT, Burkhard LP (2005) Complete elimination of carbonates: a critical step in the accurate measurement of organic and black carbon in sediments. Environmental Toxicology and Chemistry 24: 2218-2221. https://doi.org/10.1897/04-653R.1

Metzger M, Bunce RGH, Jongman RHG, Mücher CA, Watkins JW (2005) A climatic stratification of the environment of Europe. Global Ecology and Biogeography 14:549-563. https://doi.org/10. 1111/j.1466-822X.2005.00190.x

Morera-Chavarría A, Griffioen J, Behrends T (2016) Optimized sequential extraction for carbonates: quantification and $\delta 13 \mathrm{C}$ analysis of calcite, dolomite and siderite. Chemical Geology 443:146-157. https://doi.org/10.1016/j.chemgeo.2016.09.025

Nieuwenhuize J, Maas YEM, Middleburg JJ (1994) Rapid analysis of organic carbon and nitrogen in particulate materials. Marine Chemistry 45:217-224. https://doi.org/10.1016/0304-4203(94) 90005-1

Ody A, Doxaran D, Vanhellemont Q, Nechad B, Novoa S, Many G, Bourrin F, Verney R, Pairaud I, Gentili B (2016) Potential of high spatial and temporal ocean color satellite data to study the dynamics of suspended particles in a micro-tidal river plume. Remote Sensing 8:245. https://doi.org/10.3390/rs8030245

Paul D, Skrzypek G, Fórizs I (2007) Normalization of measured stable isotopic compositions to isotope reference scales - a review. Rapid Comm Mass Spectrom 21:3006-3014. https://doi.org/10.1002/rcm. 3185

Pollack JB, Kim HC, Morgan EK, Montagna PA (2011) Role of flood disturbance in natural oyster (Crassostrea virginica) population maintenance in an estuary in South Texas, USA. Estuaries and Coasts: Journal of the Estuarine Research Federation 34:187-197. https://doi.org/10.1007/s12237-010-9338-6

Pont D, Simmonet JP, Walter AV (2002) Medium-term changes in suspended sediment delivery to the ocean: consequences of catchment heterogeneity and river management (Rhône River, France). Est Coast Shelf Sci 54:1-18. https://doi.org/10.1006/ecss.2001. 0829

Pont D, Day JW, Ibañez C (2017) The impact of two large floods (19931994) on sediment deposition in the Rhône delta: implications for sustainable management. Sci Total Environ 609:251-262. https:// doi.org/10.1016/j.scitotenv.2017.07.155

Pozzato L, Rassmann J, Lansard B, Dumoulin JP, van Breugel P, Rabouille C (2018) Origin of remineralized organic matter in sediments from the Rhone River prodelta (NW Mediterranean) traced by $\triangle 14 \mathrm{C}$ and $13 \mathrm{C}$ signatures of pore water DIC. Progress in Oceanography 163:112-122. https://doi.org/10.1016/j.pocean. 2017.05.008

Wetz MS, Yoskowitz DW (2013) An "extreme future" for estuaries? Effects of extreme climatic events on estuarine water quality and ecology. Marine Pollution Bulletin 69(1-2):7-18. https://doi.org/ 10.1016/j.marpolbul.2013.01.020

Zoppini A, Ademollo N, Bensi M, Berto D, Bongiorni L, Campanelli A, Casentini B, Patrolecco L, Amalfitano S (2019) Impact of a river flood on marine water quality and planktonic microbial communities. Estuarine, Coastal and Shelf Science 224:62-72. https://doi. org/10.1016/j.ecss.2019.04.038

Publisher's note Springer Nature remains neutral with regard to jurisdictional claims in published maps and institutional affiliations. 